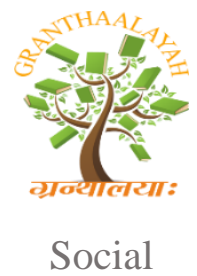

\author{
INTERNATIONAL JOURNAL OF RESEARCH - \\ GRANTHAALAYAH \\ A knowledge Repository
}

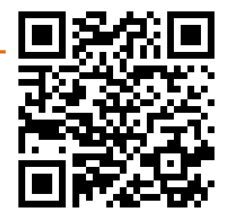

\title{
BENCHMARKING HEAD OF MADRASAH IN DOING MADRASAH TRANSFORMATION IN JAMBI PROVINCE
}

\author{
Prof. Dr. H. Mukhtar 1, M.Pd Dr. H. Kasful Anwar. US M.Pd ${ }^{2}$, Dr. Emmi Kholilah \\ Harahap M.Pd.I ${ }^{3}$
}

\begin{abstract}
The purpose of this research is to know the success of benchmarking of madrasah head in transforming madrasah, to know benchmarking of head of madrasah, to know transformation that happened at madrasah, and to know benchmarking of madrasah head to transform madrasah. The research methodology used is descriptive qualitative approach. Data collection techniques using observation, interviews and documentation. Analysis of the data using the model of Miles and Huberman and data validity technique uses triangulation data.

The results show that the success of madrasah head benchmarking in transforming with active commitment in managing madrasah, understanding the advantages and weaknesses of madrasah, innovating in madrasah, and applying benchmarking results in madrasah. Benchmarking process is self-evaluation of madrasah program, comparison with referral madrasah, reflection of madrasah performance and backbiting towards benchmarking of madrasah. The madrasah transformation covers the aspects of input, process transformation in madrasah, transformation of madrasah output and transformation of madrasah culture.

The conclusion of this research can be seen that through benchmarking the head of madrasah can make the head of madrasah do madrasah transformation. The implication of this research is that benchmarking done by head of madrasah is not necessarily self-done. This requires the responsibility and commitment of all madrasahs in it, managerial skills, adequate human resources, and empowerment of all personnel in the madrasah.
\end{abstract}

Keywords: Benchmarking; Head of Madrasah; Transformation and Madrasah.

Cite This Article: Prof. Dr. H. Mukhtar, Dr. H. Kasful Anwar, and Dr. Emmi Kholilah Harahap. (2019). "BENCHMARKING HEAD OF MADRASAH IN DOING MADRASAH TRANSFORMATION IN JAMBI PROVINCE." International Journal of Research - Granthaalayah, 7(4), 281-299. https://doi.org/10.29121/granthaalayah.v7.i4.2019.902.

\section{Introduction}

The realization of good governance in an organization is led by a leader in the organization. As a leader, of course, you must pay attention to several things related to your leadership, including: leadership style, emotional intelligence and also decision making. The leadership style displayed by a leader is an implication of his ability to manage emotional intelligence and spiritual 
intelligence. Goleman in Abd. Kadim Masaong argues that optimizing the management of emotional intelligence will produce four competency domains that are very effective in creating leadership styles, namely, domain of self-awareness, self-management, social awareness and relationship management. This shows that with good emotional intelligence there will be a good leadership style. $1 \mathrm{~A}$ leader is someone who is able to influence other people to do or not do something they want.2 Leadership reflects the assumption that leadership is related to the deliberate process of a person to emphasize his strong influence on others to guide, structure and facilitate activities and relationships within a group or organization.3 Leadership is one of the most important factors in an organization because most of the successes and failures of an organization are determined by leadership in the organization. 4

Madrasah is an organization in the form of a complex and unique educational institution. Madrasas require a high level of coordination, namely a leader. 5 The head of the madrasa is responsible for achieving educational goals. The head of the madrasa is responsible for micro-management of education, as stated in the Government Regulation article 12 paragraph 1 PP 28 of 1990.6 The task of the headmaster in learning is to encourage the teacher to work together to investigate, observe, and draw conclusions, build, and decorate themselves in accordance with the interests that exist in him and the head of the madrasa in collaboration with the teacher in this matter.7 The quality of the headmaster is one of the success factors that determine the quality of the madrasa he leads. The ability of the head of the madrasa in managing madrasa has $49.7 \%$ contribution to the quality of education while $50.3 \%$ is determined by other factors. 8 This shows the magnitude of the influence of the headmaster's managerial abilities on the development of madrasa quality. The managerial skills of the madrasa principals are generally quite good, but it is necessary to increase the managerial capacity of the madrasa principals both on the dimensions of planning, organizing, actuating, and especially on controlling aspects. 9

The inadequate managerial skills of the head of the madrasa are less supportive he transformation or renewal in the madrasa both in the aspects of input, process, output and outcome. So madrasas tend to lag behind compared to public schools. In the 2015/2016 academic year out of 31 State Aliyah Madrasas in Jambi Province there were 8 State Madrasah Aliyahs that had A accreditation score, there were 19 State Madrasah Aliyahs that had B accreditation scores and there were 4 State Aliyah Madrasas that had C accreditation values. The data showed that only $24.8 \%$ of State Islamic Senior High Schools received A accreditation scores, 10 this matter is far behind compared to public schools both. In 2015-2016 there were 148 State High Schools in Jambi Province, 35.52\% (24) received A accreditation scores, while the number of State Vocational Schools in Jambi

\footnotetext{
${ }^{1}$ Abd. Kadim Masaong dan Arfan A. Tilome, Kepemimpinan Berbasis Multiple Intelligence: Sinergi Kecerdasan Intelektual, Emosional dan Spiritual untuk Meraih Kesuksesan yang Gemilang (Bandung: ALFABETA, 2011), p. 148-150.

${ }^{2}$ M.H. Matondang, Kepemimpinan Budaya Organisasi dan Manajemen Strategik (Yogyakarta: Graha Ilmu, 2008), p. 5.

${ }^{3}$ Gary Yukl, Kepemimpinan dalam Organisasi (Jakarta: Indeks, 2015), p. 3.

${ }^{4}$ Miftah Thoha, Kepemimpinan dalam Manajemen (Jakarta: Rajawali Pers, 2012), p. 1.

${ }^{5}$ Abd. Wahab H.S. dan Umiarso, Kepemimpinan Pendidikan dan Kecerdasan Spritual (Jogjakarta: Ar-Ruzz Media, 2011), p. 114115.

${ }^{6}$ Anonim, Peraturan Pemerintah No 28 tahun. 1990.

${ }^{7}$ Rusyan, Profisionalisme Kepala sekolah (Jakarta: Pustaka Dinamika, 2012), p. 52.

${ }^{8}$ Hasan Sodiqin dan Diding Nurdin, Kemampuan Manajerial Kepala Madrasah Dan Kinerja Mengajar Guru Dalam Mutu Pendidikan (Jurnal Administrasi Pendidikan: Vol. XXIII No.2, 2016) hlm. 95.

${ }^{9}$ Ibid., p. 99.

${ }^{10}$ Data EMISPENDIS Madasah Provinsi Jambi, 2015-2016.
} 
Province was 92 and those who got A accreditation score of 31.28\% (34).11 he disadvantage of madrasah aliyah compared to public high schools cannot be left alone because since the birth of Law No. 2 of 1989 concerning the National Education System. madrasas have the same position as general education institutions in general. For this reason, an active role and professionalism is needed from the head of the madrasa as a leader who should have big dreams, willingness, intelligence and courage to realize with full commitment and responsibility to improve the quality and quality of the madrasa he leads. The willingness and desire for quality and quality is in the effective head of school / madrasah. Martin and Millower and Willower and Kmetz in Mulyasa based on the results of their studies on various excellent schools that have successfully developed their programs, put forward the indicators of effective principals / madrasas as follows: a) have a strong vision of the future of their school, b) have hope high, c) ensuring effective learning, d) efficient use of time and minimizing stress and negative conflict, e) utilizing various learning resources, f) utilizing information to guide learning planning, and g) conducting continuous evaluation and improvement. 12

There are two types of quality improvement, namely improving quality to achieve established quality standards and improving quality in the context of increasing quality standards that have been achieved through benchmarking. Benchmarking is one of the efforts made by the head of the madrasa to make improvements in madrasa management which lead to the transformation of the madrasa. Benchmarking which is a measure will be used as a performance benchmark in the madrasa. Benchmarking is the process of comparing and measuring the operation of an organization or its internal processes with operations or work processes of the best performance in its class that comes from inside or outside the industry.13 In general, the benefits obtained from benchmarking can be grouped into three major groups, namely (1) cultural transformation, (2) performance improvement, (3) improvement in human resource capabilities.14

The head of the madrasa in conducting benchmarking at the madrasa he leads must have a standard guideline which is a reference in the benchmarking process in his madrasa. Based on the national education standards set by the government regarding the quality of education, the guidelines for benchmarking must also be based on national education standards which include graduate competency standards (SKL), standard content (SI), process standards, educator standards and education personnel, standard facilities and infrastructure, management standards, assessment standards, and financing standards.

Information obtained about benchmarking the madrasa principals in three madrassas located in three regions in Jambi Province, namely MAN 1 Jambi City, MAN 2 Tebo, and MAN 1 Batang Hari. In detail the results of the grand tour conducted by researchers.

\subsection{MAN 1 Jambi City}

The direct visit that has been carried out by the head of the madrasah MAN 1 Jambi City in carrying out benchmarking on educational institutions is at MAN 1 Malang. The long-term work program

\footnotetext{
${ }^{11}$ Data Akreditas Sekolah, Dinas Pendidikan Provinsi Jambi, 2015-2016.

${ }^{12}$ E. Mulyasa, Manajemen dan Kepemimpinan Kepala Sekolah (Jakarta: Bumi Aksara, 2015), p. 21-22.

${ }^{13}$ M. Nur Nasution, Manajemen Mutu Terpadu: Total Quality Management (Bogor: Gpia Indonesia, 2015), p. 234.

${ }^{14}$ Fandy Tjiptono dan Anastasia Diana, Op. Cit., p. 237-238.
} 
compiled based on the benchmarking results of the madrasa head can be seen in the program matrix for the 2015-2019 MAN 1 Jambi City program, namely: (1). Construction of parking lots for 2wheeled vehicles, (2). Construction of prayer rooms, (3). Acceptance of new students, (4). Make rules for madrasa, (5). Increasing teacher competence, (6). Construction of sports facilities and infrastructure, (7). Improve student skills in the field of Islamic music, and (8). Improve student skills in the field of organization. The achievement of the performance of MAN 1 in Jambi City based on the strategic target as a whole in 2015 was $99.70 \%$.

\subsection{MAN 2 Tebo}

Direct visits that have been made by MAN 2 Tebo madrasah principals since 2015 to educational institutions, namely the MAN Model Jambi City. The achievement of MAN 2 Tebo's performance based on the strategic target in the overall average in 2015 was $95.77 \%$. The long-term work program compiled based on the benchmarking results of the madrasa head can be seen in the 20152019 MAN 2 Tebo program program matrix as follows: (1). Madrasah quality improvement, (2). Improve office and maintenance operations, (3). Improve management of education and service tasks in Islamic education, (4). Increasing public services and bureaucracy, (5). Providing assistance to poor students in madrasas, (6). Hold training for students, teachers and employees on an ongoing basis, (6). Holding a ceremony before the lesson begins, the dzuhur prayer in congregation, the commemoration of Islamic holidays, and forming groups of religious study / evaluation of students, and (7). Intensify communication and cooperation with parents.

\subsection{MAN 1 Batang Hari}

The direct visits that have been made by MAN 1 Batang Hari to educational institutions include: MAN 19 Jakarta and MAN 1 Yogyakarta. The long-term work program based on the results of benchmarking conducted by the head of the madrasah can be seen from the 2011-2019 MAN 1 Batang Hari program program matrix as follows: (1). The attendance of students, teachers and employees is more than $95 \%$, (2). The average achievement target for graduate UAN is 6.5, (3). The target of achieving 20\% of graduates can be accepted at PTN either through PMDK or UMPTN, (4). MAN 1 Batang Alumni Day 60\% go to university, high school, university, or private academy, (5). MAN 1 Batang Hari learners $90 \%$ of students who are Muslim can read the Koran properly and correctly, (6). Students of MAN 1 Batang Hari 90\% joined the dzuhur prayer in congregation at Musalla Al-Ikhlas MAN 1 Batang Hari, (7). Students of MAN 1 Batang Hari 75\% can Kultum after joining the dzuhur prayer in congregation at Musalla Al-Ikhlas MAN 1 Batang Hari, (8). Students of MAN 1 Batang Hari 85\% can read prayer, lead yasinan, (9). Students of MAN 1 Batang Hari $85 \%$ took part in afternoon tutoring activities at MAN 1 Batang Hari, (10). Students of MAN 1 Batang Hari 70\% have textbooks, (11). Students of MAN 1 Batang Hari Mastered and competed in academic and non-academic competitions (sports and arts) in high school environments in Batang Hari Regency and Madrasah neighborhoods in Jambi Province, (12). Cultivate madrasa productive land to contribute to the welfare of the madrasa family, (13). MAN 1 Batang Hari teachers $80 \%$ can operate computers proficiently, (14). Teachers of MAN 1 Batang Today $70 \%$ have laptops and can access the internet independently to enrich the learning process. The achievement of performance in MAN 1 Batang Hari is based on the strategic target, the overall average in 2015 is $99.75 \%$ of the planned work program plan to be implemented. 
Information obtained about the transformation of madrasas is seen from the madrasa data on madrasa structure, madrasa infrastructure, media and madrasa equipment, data on madrasah educators and education staff and operational standard data on madrasas over the past 5 years in three madrasas located in three regions in Jambi Province namely MAN 1 Jambi City, MAN 2 Tebo, and MAN 1 Batang Hari.

\section{Rumusan Masalah}

Based on the preliminary study that became the background of the problem in this study, the formulation of the problems raised in this study will be the core of the discussion that will be discussed in the research findings, then the formulation of the main problem is as far as the benchmarking of the madrasa head in transforming the madrasa.

\section{Theory Study}

\subsection{Benchmarking of Madrasah Heads}

In the era of madrasa independence and the era of school-based management (SBM), the duties and responsibilities are large in the development of educational institutions. Because madrasa has the authority to regulate everything in a madrasa institution. In order for the tasks and responsibilities of the madrasa to become evident, the madrasa needs to understand, explore and apply several management science concepts that have been developed by thinkers in the business world, namely TQM (total quality management) or integrated quality management which instensely applied in education. The implementation of TQM in educational institutions in principle for education quality assurance that leads to customer satisfaction. ${ }^{15}$

The quality assurance process is not only an activity to ensure that what is promised can be fulfilled but also includes ongoing quality improvement efforts through planning and carrying out activities, internal monitoring and evaluation, self evaluation, audit, and benchmarking. The quality assurance cycle begins with the determination of quality standards to be achieved within a certain period of time and then this standard is carried out with the utmost effort to be fulfilled. To see the progress of the implementation of the standard and to ensure that the direction of implementation is in accordance with the plan, monitoring and evaluation needs to be done. Self-evaluation is carried out mainly to see the strengths and weaknesses of the rules of education in relation to standard compliance efforts. The next stage is an internal quality audit to see compliance with established quality standards. The results obtained from the stages of monitoring and evaluation, self-evaluation, and internal quality audits as well as input from all stakeholders, are used as consideration in making quality improvements. Quality assurance in educational institutions contains several elements or often known as national education standards covering eight aspects of national education standards consisting of standard content, processes, graduate competencies, education staff, facilities and infrastructure, management, financing, and educational assessments that must be improved on a plan and periodic basis.16

\footnotetext{
${ }_{15}$ Mustajab, Trilogi Membangun Sekolah Unggul: Kepemimpinan, Budaya Mutu, Benchmarking, (Kebumen: Jurnal Saintifika Islamica IAINU Kebumen, Vol.2 No. 2, 2015), p. 103.

${ }^{16}$ Teguh Triwiyanto, Standar Nasional Pendidikan Sebagai Indikator Mutu Layanan Manajemen Sekolah (Malang: Jurnal Ilmu Pendidikan Universitas Negeri Malang, Vol 19. No. 2, 2013), p. 162.
} 
The application of TQM is not just a management program aimed at complementary or sweetener activities, but is indeed needed to improve the quality of work productivity. TQM must be goaloriented, so that organizational performance is more effective.17 The meaning of management itself is a process to achieve organizational goals by carrying out activities from four main functions, namely planning, organizing, actuating, and controlling.18

The term total quality management education in Indonesia is known as integrated education quality management. The integrated education quality management definition includes two components namely what and how to run integrated education quality management. In integrated education quality management, the customer is the one who is in power or as the king who is served as well as possible. Integrated education quality management is an approach that guarantees continuous change in the focus of schools / madrasas from short-term to long-term policies. Innovation, improvement and change are constantly a concern for madrasas and make it a circle of continuous improvement activities. To develop a culture of continuous improvement, the principal's first task is to give trust to the citizens of his madrasa and delegate authority at the appropriate level so that his staff is also responsible for quality improvement.

Integrated Quality Management education has five main pillars in its application. Creech in Husaini Usman suggested strengthening five pillars that support integrated quality management. The five pillars are the product, process, organization, leadership and commitment of all people in the organization. On the five pillars, total quality management of goods or services products is the livelihood chain of an organization. Quality products will not be achieved without a quality work process. Quality work processes will not arise without a well-managed organization. The organization will be in vain without the right leadership. The four pillars above will be in vain without any commitment from all parties involved to improve quality.

Students are customers from madrasas, so the products in the Integrated education quality management process are graduates who are of good quality from intellectual competence, social competence, and expertise competencies. Quality graduates will not be achieved without a quality madrasah management process. Quality management processes for madrasas will not arise without the existence of well-managed organizations / madrasas, and madrassas will be in vain without the right leadership of the madrasa principals, because $49.7 \%$ of the principals' managerial skills will affect the quality of madrasas.

Integrated education quality management main mission is to meet customer satisfaction. According to Peter and Waterman in Husaini all organizations that want to maintain their existence must be obsessed with quality. Quality must be in accordance with the requirements desired by the customer. Quality is the customer's desire not the desire of the madrasa. Without the quality that is in accordance with the wishes of the customer, the madrasa will lose its customers will close or disband. Even though the madrasa has been focused on the customer, not by itself is an adequate condition to ensure total quality. Madrasas still need a complete strategy to find the requirements customers want. Madrasas face severe challenges in dealing with external customers because their expectations vary and sometimes do not match the reputation of the madrasa. For this reason

\footnotetext{
${ }^{17}$ Ibid., p. 105.

${ }^{18}$ Baharuddin dan Umiarso, Kepemimpinan Pendidikan Islam Antara teori dan Praktek (Yokjakarta: Ar-Ruzz Media, 2012), p. 372.
} 
integrated education quality management is a practice in the form of a strategic approach to organize madrasas that focus on customer needs.

In order for quality to be maintained and the quality improvement process to be controlled, then there must be a nationally regulating and agreed standard to be used as an indicator of evaluating the success of quality improvement (ie benchmarking) because benchmarking is one of the evaluation tools used in implementing total quality management education. Benchmarking is a positive and proactive activity that focuses on finding the best practice, which directs superiority.19 Benchmarking is a concept in which the objectives formulated must be achieved because this has been achieved by other companies.20 Gregory $\mathrm{H}$. Watson explained that in benchmarking with the APQC concept. The APQC study resulted in the recognition of four basic steps in the benchmarking process, namely: 1. Planning a benchmarking project, 2 . Gathering the required data, 3 . Analyzing data about performance gaps and determinants, and 4. Developing and adapting the determinants of the process. 21

Improving the organization through benchmarking that leads to organizational transformation can be done with the concept of business process reengineering (BPR). In conducting benchmarking in the concept of reengineering according to Bennis and Mische in Bhaswara et al,22 done in the following stages: stage 1: creating a vision and setting goals, stage 2: benchmarking and defining success, stage 3: innovating the process, stage 4: transforming the organization, stage 5: monitoring the process that is reengineered.

The engineering theory model: Business Process Reenguneering (BPR) proposed by Bennis and Mische as an effort to improve madrasas was used in this study. Benchmarking carried out in an organization according to Bennis and Mische includes several activities, namely: 1. benchmarking practices, 2 . identifying best practices, 3. assessing information technology, 4. setting performance targets. The benchmarking process carried out in organizations will make the organization transformed towards organizational improvement which includes 1. transforming operations, 2. transforming structures, 3. implementing reengineered processes. In general, the benefits obtained from benchmarking can be grouped into three major groups, namely (1) cultural transformation, (2) (3) improvement in human resource capabilities..23

The headmaster's benchmarking referred to in this paper is the process of comparing and measuring madrasah operations from the best performance originating from outside the madrasah conducted by the headmaster. Indicators of the madrasa head benchmarking are: 1. conduct a madrasah program self-evaluation, 2 . make a comparison with the referral madrasa, 3 . reflect on the performance of the madrasa, 4 . make a madrasa improvement plan, 5. make improvements to the madrasa, 6. do feedback.

\footnotetext{
${ }^{19}$ Amin Widjaja Tunggal, Manajemen Mutu Terpadu Suatu Pengantar (Jakarta: Rineka Cipta, 2005), p. 110-111.

${ }^{20}$ M. Nur Nasution, Manajemen Mutu Terpadu (Total Quality Management) (Bogor: Gpia Indonesia, 2015), p. 234.

${ }^{21}$ Gregory H. Watson, Strategic Benchmarking, Mengukur Kinerja Perusahaan Anda Dibandingkan Perusahaan-Perusahaan Terbaik Dunia (Jakarta: Gramedia Pustaka Utama 1996), p. 68-69.

${ }_{22}$ Bhaswara Aditya Wardhana, dkk, Usulan Perbaikan Proses Bisnis Dengan Konsep Business Process Reengineering: (Studi Kasus Permata Guest House, Jurnal Jati Undip, Vol. VIII, No. 1. 2013.

${ }^{23}$ Fandy Tjiptono dan Anastasia Diana,Op. Cit., p. 237-238.
} 


\subsection{Transformasi Madrasah}

Organizational transformation is a move in a better direction to maintain the existence of the organization against the demands of the transformation of the age..24 This transformation can occur in organizational structure, work mechanism processes, human resources, and culture. The purpose of transformation is to improve the organization to adapt to environmental transformation and on the other hand seek employee behavior transformation. Environmental transformation can be an external and internal environment of the organization. Winardi also explained that in the transformation process there are forces that help to make the transformation process work well, namely competitive forces, economic and political forces, global forces, demographic forces and social forces and ethical forces. 25

Kurt Lewin in Stephen P. Robbins argues that successful transformation in the organization should follow three steps of unfreezing the status quo, movement to a new state, and freezing (refrezing new transformations to make it permanent. Kartini Kartono also explained that some important issues what needs to be considered in the transformation process that can provide facilities for the ease of transformation are as follows: First the transformation requires time, both organizational structures are unique, the three balances between costs and benefits, four effective communication.five anxiety about things that have not known to be in need of control Sixth active participation of executive executives Seventh enforcement process Because the attitudes and behavior of the adult are a lot of "grilling" and relatively fixed, the habitual patterns and attitudes are not as easy as one might expect Bro $\mathrm{n}$ continuous progress.

There are several transformation theories put forward by several figures. First: Force-Field Theory by Kurt Lewin in Didin Kurniadin. Kurt Lewin was introduced as the father of transformation management because he was considered the first person in the social sciences and specifically carried out studies on scientific transformation. The concept is known as the Force-Field model which is classified as a power based model because it emphasizes emphasis forces. According to him, transformation occurs because of the emergence of pressures on organizations, individuals or groups. He concluded that the pressure force (driving force) would be faced with resistance (resistences) to transform. Transformation can occur by strengthening Driving Force in weakening resistance to change. The steps that can be taken to manage the transformation are as follows: (1) Unfreezing, (2) (3) Refresing. Second: Motivation Theory by Berckhard Dan Harris in Didin Kurniadin. Berckhard and Harris formulated motivational theories to change. They conclude the transformation will occur if there are a number of the following conditions. (1) Benefit-costs ... (2) Dissatisfaction. (3) Tomorrow's perception. (4) Practical ways that can be taken to get out of the current situation. Third: the theory of the process of managerial transformation by Berr in Didin Kurniadin. This theory was developed by managerial school of thought. Through his studies, he found the importance of involving so many people in transformation. In managerial school of thought, researchers also use body of knowledge from other sciences, especially psychology and socology, so that this theory adopts the importance of efforts to reduce stress in the transformation and design of more satisfying work. According to this theory, to produce managerial transformation, the following things need to be done. (1) Mobilizing the energy of stakeholders to support transformation, involving them in analyzing and diagnosing problems that hinder

\footnotetext{
${ }^{24}$ Husaini Usman, Op. Cit., p. 259-260.

${ }^{25}$ Winardi, Manajemen Perubahan (Jakarta: Kencana Prenada Media Group, 2008), p. 2-3.
} 
organizational competitiveness. (2) Develop a vision and strategy to manage and produce positive competitiveness. (3) Seek consensus on a new vision so that the vision is accepted as truth and done without conflict. (4) Expanding revitalization in all departments in the organization. (5) Consolidate transformation through formulated strategy policies, structures, systems, etc. (6) Monitor this activity continuously. Fourth: Contingency theory by Tannenbaum and Schmidt in Didin Kurniadin. The success of explaining management transformation, among others, is largely determined by the style adopted by management. This theory argues for the degree of success of decision making. The success rate of various leadership styles is closely related to a number of contingencies. Fifth: the theory of cooperation by Williams in Didin Kurniadin. Transformation usually does not work without the cooperation of all parties. Collaboration theory explains why humans are willing to cooperate and how to get cooperation. There are several explanations for why humans want to work together, including the following. (1) Motivation to get Rewards or worry about getting penalties / sanctions. (2) Motivation of loyalty to the profession, work or company. (3) Moral motivation because working together can be morally acceptable. (4) Motivation to carry out expertise. (5) Motivation because it is in accordance with the attitude of life. (6) Motivation of obedience to power.26 ixth: system theory by Chester Barnand was developed by Stephen P. Robbins and Mary Coulter.

At the school level, it is known as the education reform discourse. The initiative to make educational reform discourse into reality is not impossible, if the main pillars of education development (government, society, schools and communications, and other conditional aspects support it. David Conley in Sudarwan Danim has identified twelve major dimensions of education reform, where it will become a significant new foundation for school management restructuring, namely: learning standards, curriculum, learning process, assessment, learning environment, technology, school-community relations, learning and teaching time, management or management of education, leadership of principals and teachers, personnel and contractual relationships.

Effective madrasas have diverse indicators but lead to the quality of learning outcomes. Uhar Suharsaputra views Madrasas as effective from three perspectives, namely 1) madrasas are effective in the perspective of education quality, 2) madrasas are effective in the management perspective, and 3) madrasas are effective in the perspective of organism theory:27 First, madrasas are effective in the perspective of education quality, namely: the implementation of learning services for students is usually studied in the context of quality education that is closely related to the quality management study and effective Madrasah.28 Both madrasas are effective in the management perspective, namely: In general, management is always interpreted as a form of management of an organization's activities. So there is an action to organize, organize, and manage activities and people in an organization in planning, organizing, implementing, mobilizing, controlling, leading, motivating, monitoring, evaluating, and so forth.29 Bambang Ismaya explained that the presence of managers who have the ability and skills about human relations to influence others in order to achieve effective and efficient organizational goals.30

\footnotetext{
${ }^{26}$ Didin Kurniadin dan Imam Macpi, Op. Cit., p. 283-286.

${ }^{27}$ Uhar Suharsaputra, Administrasi Pendidikan (Bandung: Rosdakarya, 2010), p. 37.

${ }^{28}$ Sudarwan Danim, Visi Baru Manajemen Madrasah (Jakarta: Bumi Aksara, 2010), p. 51-53.

${ }^{29}$ Onimus Amtu, Manajemen Pendidikan di Era Otonomi Daerah (Bandung: Afabeta, 2013), p. 30.

30 Bambang Ismaya, Pengelolaan Pendidikan (Bandung, Refika Aditama, 2015), p. 3
} 
Djam'an Satori in Uhar31 put forward effective madrasas in a management perspective, is the process of utilizing all madrasa resources carried out through rational and systematic actions (including planning, organizing, directing actions, and controlling) to achieve the goals of madrasas effectively and efficiently. Whereas according to Syafaruddin effective schools are schools that have results through good input, process, and output, in which management and leadership are found to be able to direct all school resources in the interest of achieving school goals, there are job satisfaction of personnel, and qualified graduates directing school changes antissively and productively. 32

According to the Ministry of National Education (Depdiknas) in Nur Efendi explained, schools are said to be good if they have eight criteria: (1) students who enter are rigorously selected and can be accounted for based on academic achievement, psychological tests and physical tests; (2) educational facilities and infrastructure are fulfilled and conducive to the learning process, (3) climate and supportive atmosphere for learning activities, (4) teachers and education staff have high professionalism and adequate level of welfare, (5) improvise curriculum so that it meets the needs of students who generally have a high learning motivation compared to their age students, (6) student learning hours are generally longer because of the demands of the curriculum and student learning needs, (7) the learning process is more qualified and accountable to students and guardians of students, and ( 8) superior schools benefit the environment.33

Furthermore, if viewed in this perspective, the dimensions and indicators of an effective madrasah can be described as follows:34 First: learning services for students. Second: the quality of teaching teachers.35 According to Mulyasa, there are three conditions that must be considered in educational development so that they can contribute to the improvement of the quality of human resources, namely: (1) professional teachers and education staff; (2) building facilities; and (3) quality books.36 Third: smooth teaching and learning services. Fourth: feedback received by students. Fifth: the daily service of teachers to students. Udin revealed that the characteristics of a professional teacher could be stated, namely: (1) having commitment to the organizational culture or commitment to the learning process of students; (2) master in depth the subject matter and how to teach it; (3) able to think systematically about what is done and learn from their experiences; and (4) is part of the community learning from their professional environment which enables them to increase their professionalism.37 Sixth: the comfort of the classroom. Seventh: availability of learning facilities. Eighth: the opportunity for students to use various madrasa facilities. Ninth: student management and service. Tenth: madrasa facilities and infrastructure. Eleventh: programs and financing. Twelfth: community participation. Thirteenth: madrasa culture. The three madrassas are effective in the perspective of organism theory, namely: Garmston and Wellman in Uhar states that effective madrasas are madrassas that are able to realize what are called self-

\footnotetext{
${ }^{31}$ Uhar Suharsaputra, Op. Cit., p. 38.

32 Syafaruddin. Efektivitas Kebijakan Pendidikan: Konsep, Strategi, dan Aplikasi Kebijakan Menuju Organisasi Sekolah Efektif (Jakarta: Rineka Cipta, 2008), p. 182.

${ }^{33}$ Nur Efendi, Membangun Sekolah Efektif dan Unggul (Yogyakarta: Lingkar Media, 2014) p. 20.

${ }^{34}$ Onimus Amtu, Loc. Cit.

35 Direktorat Tenaga Kependidikan, Supervisi Akademik Dalam Peningkatan Profesionalisme Guru (Jakarta: Departemen Pendidikan Nasioanal, 2007), p. 1.

${ }^{36}$ E. Mulyasa, Menjadi Guru Profesional Menciptakan Pembelajaran Kreatif dan Menyenangkan (Bandung: Remaja Rosdakarya, 2008), p. 3.

37 Udin Syafaruddin Saud, Pengembangan Profesi Guru (Bandung: Alfabeta, 2009), p. 97.
} 
renewing schools or adaptive schools, which is a condition where the madrasa institution as an entity is able to handle the problems it faces, and able to innovate. 38

The transformation of madrasas referred to in this research is a process in which there is a shift from the prevailing conditions towards the desired conditions carried out by individuals, groups within the madrasa in terms of reacting to internal and external dynamic forces. Indicators of madrasa transformation are 1. transformation of madrasa organizational structure, 2. transformation of media and equipment in madrasas, 3. transformation of madrasah spatial arrangements, 4. transformation of madrasah educators and education staff, 5. transformation of the learning process in madrasas, 6. transformation madrasa culture.

\section{Metodologi Penelitian}

This study uses a descriptive qualitative research approach, where the study of the headmaster's benchmarking in this study uses descriptive methods.39 This research was conducted in the form of descriptive qualitative analysis, because this research is non-hypothesis which does not require statistical formulas. When viewed from the nature of the process and data analysis, it can be classified into descriptive explorative research.40 The instruments used to obtain data in this study are participatory observation (participant observation), interviews and documentation studies.

In this study, researchers used content analysis, because the approach of this study was descriptive qualitative in which the data obtained requires descriptive explanation in depth. Data analysis will be carried out in this study by following the steps as follows:41 1. Process and prepare data for analysis, 2. Read the entire data. 3. Analyze in more detail by coding data. 4. Implement the coding process to describe settings, people, categories and themes to be analyzed. 5. Describe these themes for restatement in the form of qualitative narratives / reports. 6. Interpret data.

Analysis of the data used in this study with the models of Miles and Huberman.42 As for achieving that trust, the following steps are taken: 1) Comparing observational data with interview data 2) Comparing what people say in public with what is said personally. 3) Comparing what people say about the research situation with what they say all the time. 4) Comparing a person's situation and perspective with various opinions and views of the people from various classes. 5) Compare the results of interviews with the contents of a related document. There are three examinations of the data used in this study, namely the extension of participation, increasing observation perseverance, triangulation.

\section{Research Findings and Analysis of Research Results}

Benchmarking madrassas as an effort to improve the quality and quality of madrasas is based on the wishes of the madrasa based on the desire to improve the quality of madrasas. This desire is

\footnotetext{
${ }^{38}$ Uhar Suharsaputra, Op. Cit., p. 38.

${ }^{39}$ Basrowi dan Suwandi, Memahami Penenlitian Kualitatif (Jakarta: Rineka Cipta, 2009), p. 23.

${ }^{40}$ Nana Syaodih Sukmadinata, Metode Penelitian Pendidikan (Bandung: Program Pascasarjana Universitas Pendidikan Indonesia, Remaja Rosdakarya, 2007), p. 60-61.

${ }^{41}$ John. W. Creswell, Op. Cit., p. 275-284.

42 Matthew B. Miles \& A. Michael Huberman, Analisis Data Kualitatif: buku sumber tentang Metode-metode Baru (Jakarta: UIPres, 1992), p. 15-20.
} 
based on the low value of accreditation, the desire of the madrasa to make superior madrasas, quality competitive both nationally and globally, improve the quality of the learning process, improve the quality of educators and education staff, improve the quality and benefits of facilities and infrastructure, improve quality madrasa curriculum in order to have conformity with the characteristics of students in the madrasa and also to improve the quality of academic management in the madrasa both management of academic services, finance and the implementation of evaluations in the madrasa.

The success achieved by the head of the madrasa in carrying out the benchmarking process in the madrasa he leads, namely in MAN 1 Jambi City, MAN 2 Tebo and MAN 1 Batang Hari can be seen from the capabilities of the headmaster in performing his duties in managing the madrasa. The need to carry out the benchmarking of the marasah head as an effort to improve the quality of madrasa oriented to customer satisfaction, improve the quality of madrasa management that can be accounted for, madrasa management that has a system of openness with the community, maximizes the management of facilities and infrastructure, implements madrasa culture and enhances human resource capacity (leaders, educators and education staff), improve the quality of madrasah graduates, improve curriculum quality, learning methods and learning evaluation. In addition to improving the quality of the madrasa, it is also based on the desire to innovate in the madrasa by looking at developments in other madrasas and through media that can provide information to the head of the madrasa about the development of education in accordance with current global demands. In addition, another reason is to be able to take preventive actions in implementing madrasah management. Madrasah quality improvement will also provide awareness to see the extent to which madrasas achieve by assessing and reviewing the economy, efficiency, weaknesses and shortcomings in the madrasa.

The activities that become the success of the madrasa head in benchmarking are: First active commitment from the head of the madrasa in managing madrasa to direct the implementation of benchmarking in the madrasa the two principals understand the strengths and weaknesses of achieving the results of madrasah management. Third The desire to change from the Head of Madrasah by innovating in the madrasa based on benchmarking findings. The four Madrasah Heads conduct a continuous benchmarking effort Continuous benchmarking effort The process by the head of the madrasa in benchmarking is:

\subsection{Conduct Self Evaluation}

The first step taken by the principal in conducting benchmarking in the madrasa they lead is by conducting a self-evaluation. In conducting a self-evaluation, there are a number of things that are evaluated, namely: First: evaluation of standard content which includes a). evaluation of the achievement of the madrasas vision, mission and objectives, b). evaluation of curriculum implementation for subjects that have been developed, c). mulok development evaluation, d). self development evaluation, e). evaluation of life skills education and f). evaluation of education based on local and global excellence. Second, the madrasah evaluates the standard processes that include a). evaluation of the preparation and development of syllabus, b). evaluation of RPP preparation, c). evaluation and supervision of learning process activities, d). evaluation of the results of the preparation of materials / learning assessment / evaluation tools, e). evaluation of the results of the learning process analysis, f). evaluation of preparation of teaching materials. The third step is to 
evaluate the standards of educators and education personnel which include a). calculate the number of educators who meet the minimum standards, and b). observation and assessment of the learning process activities using information technology.

\subsection{Comparing with Referral Madrasas}

The direct visit that has been carried out by the head of the madrasah MAN 1 Jambi City in carrying out benchmarking on educational institutions is at MAN 1 Malang. Direct visits that have been made by MAN 2 Tebo madrasah principals since 2015 to educational institutions, namely the Jambi City Model MAN. The direct visits made by MAN 1 Batang Hari to educational institutions include: MAN 19 Jakarta and MAN 1 Yogyakarta.

\subsection{Reflect on Madrasah Performance}

Data analysis carried out by the madrasa principals through reflection on the performance of the madrasa is as follows: Organizing data to identify performance gaps. Compare performance between the institutions themselves and those of the destination. Identify performance gaps and determine the main causes. Projecting performance for the next three to five years (discussing education issues). Evaluate these determinants to be applied by adjusting the institution's own culture.

\subsection{Plan and implement Madrasah Improvement}

Planning and implementing improvements in the madrasa is carried out in the following steps: Thinking carefully about what actions need to be taken, communicating (socializing) the best alternative alternatives to all madrasa citizens, mobilizing support from all citizens of the madrasa, Taking actions that have been designed to achieve improvement

\subsection{Conducting a Turnover Against Results of Benchmarking in Madrasahs}

The head of the madrasa is to observe and assess carefully what has been done and the results that have been achieved. The biggest contribution that can be taken from benchmarking in Jambi City MAN 1, MAN 2 Tebo and MAN 1 Batang Hari is about the performance of stakeholders in the three MANs that lead to the success of the learning process in the madrasa.

The transformation that has been carried out in three Madrasas in Jambi Province.

\subsubsection{Transformation of Inputs in Madrasas}

Transforming the input aspects in the MAN 1 Jambi City environment can be seen below.

- Leadership of Madrasah Heads

- Selection of New Student Admissions

- Coaching / Training of Educators and Education Personnel

- Education Financing

- Learning Facilities and Infrastructure

- Division of Tasks on Stakeholders 


\subsubsection{Process Transformation in Madrasas}

Transforming the learning process in MAN 1 Kota Jambi is done with

- Habit of religious values to students.

- Implement rules in wearing in the madrasa environment.

- Each student is also required to attend the flag ceremony

- Enforcement of student rules of conduct,

\subsubsection{Output Transformation in Madrasas}

Transformation in the output aspect of MAN 1 in Jambi City, namely students mastering various disciplines, there are expertise of certain species, able to speak and write Arabic and English correctly, skilled in writing and speaking Indonesian, ready to compete to enter Higher Education, inside and outside quality country. transformation on cultural aspects in MAN 1 Jambi City with the implementation of the order that became the culture of the madrasa in MAN 1 Jambi City, began the habit of behaving discipline both in the classroom and in the madrasa, performing the midday prayer in congregation, cultivating smiles, greetings, greetings, polite and well mannered to the teachers and fellow students in Madrasah, not only that the application of the leadership of MAN 1 Jambi City in changing the behavior patterns of teachers and students in MAN 1 Jambi City.

MAN 1 Jambi City has an Islamic nuance in the classroom in the teaching and learning process, students are accustomed to pray before the lesson begins, the teachers in delivering the subject matter always correlate and integrate with Islamic teachings in the Koran and Hadith. Outside the class the students actively carry out the zhuhur prayer in congregation with the teachers, the students actively carry out the worship of circumcision Dhuha prayers, students are active in the internal organization of Islam by carrying out the Islamic Great Day Commemoration, nasyid group and tahfiz al-quran. Applying Culture 11 diseases that must be treated by teachers whose purpose is that teachers always improve their quality. Likewise with the implementation of the $5 \mathrm{~S}$ Culture: smile, greetings, greetings, courtesy and courtesy.

The benchmarking implementation in three madrassas, namely MAN 1 Jambi City, MAN 2 Tebo, MAN 1 Batang Hari had similarities and differences. Equations that exist in the benchmarking process in three madrasas in terms of objectives are to improve the quality of madrasah quality oriented to customer satisfaction, improve the quality of madrasah management, and achieve madrasah management in accordance with national education standards namely graduate competency (SKL), standard content (SI), process standards, standards of educators and education personnel, standards of facilities and infrastructure, management standards, assessment standards, and financing standards.

Aside from the aspect of objectives, similarities also exist in the process of implementing benchmarking for madrasah principals in three madrasas, namely conducting internal benchmarking and competitive benchmarking. Internal benchmarking is the implementation of benchmarking with the units within the madrasa itself, in other words the existence of learning activities and learning the successes made by co-workers in the madrasa and applied to the unit management process in the madrasa without overriding the goals and abilities of work unit itself. 
Whereas competitive benchmarking is done by visiting various similar educational institutions, namely to madrasas that are considered superior and successful in implementing madrasah management, in addition to implementing madrasa management that is oriented towards achieving quality madrasas that are in accordance with national education standards in Indonesia.

The equality in the aspects of the objectives and implementation stated above, does not necessarily make the three madrassas similar without difference like a split nut in two. Although in essence the same, basically every madrasa will have a different goal orientation and it is fitrah as well as selling value to parents to choose the madrasa to be a suitable place to educate children in accordance with the purpose of education in their family environment.

In accordance with the vision and mission of each madrasa, the direction of benchmarking is also adjusted to the vision and madrasa. The vision and mission set by the madrasa are essentially ideals that are used as guidelines in the implementation of madrasah management. The vision and mission have been reviewed based on SWOT analysis by looking at the strengths, weaknesses, opportunities and challenges that exist in the madrasa including managerial skills of the headmaster, the quality of madrasa human resources, support from the community as well as madrasa customers, availability of madrasah facilities and infrastructure and what is equally important is the culture of society that is directly or indirectly integrated and compatible with the culture of the madrasa, because the people in the madrasa are agents of change towards the culture of society.

Based on the results of research conducted by researchers through observation, documentation and interviews, the researchers saw that in MAN 1 Jambi City the management process through benchmarking conducted in MAN 1 Jambi City was oriented towards improving the quality of learning, improving madrasa culture, namely discipline, politeness, compliance and concern for the surrounding environment both in the madrasa and outside the madrasa, and integrating religious values in learning activities in the madrasa and the formation of character of students. This is in line with the vision and mission of the madrasa, namely the vision of "the realization of graduates of MAN 1 Jambi City having the authority and mastering science and technology". In carrying out the benchmarking process in the madrasa, the researcher saw that the good managerial skills of the madrasa principals could deliver the transformed madrasa in accordance with the ideals of the madrasa with a transformative and charismatic headmaster style leadership style. Transformative is seen from the ability of the headmaster to bring the madrasa to make changes. The head of a charismatic madrasa is seen from the ability of the headmaster to invite, influence his subordinates and obedience from his subordinates in carrying out the tasks given by the headmaster. The researcher saw that in essence the implementation of benchmarking in the environment of MAN 1 Jambi City could be increased even more if all citizens of the madrasa could maximize all existing potential by increasing work ethic and increasing work professionalism, improving human resource capabilities, the desire to move forward and change from all parties madrasas, do not feel left behind compared to other madrassas and increase the sense of responsibility for the tasks that have been given. By maximizing all the potential that exists and the desire to improve the quality and quantity of madrasah quality, it will make the madrasa transform with a quality culture. 
The implementation of madrasah management through Benchmarking conducted at MAN 2 Tebo is oriented towards improving the quality of learning quality and making students superior and pretentious. The improvement of the quality of learning aims to foster the character of students through various learning activities in the madrasa both curricular and extracurricular. The environment of madrasas both physically and non-physically also supports efforts to support the formation of students' character. From a physical point along the madrasa hall a pamphlet containing writing in the form of motivation, guidance, invitation and direction was made. This is done as an effort to shape the character of students. By placing the famlet along the porch / aisle of the madrasa, students will read it if it passes through the terrace of the madrasa and if it is often read it will be embedded in its memory and will slowly be carried out as well. In addition, the culture in the madrasa is also made in such a way through the cultivation of discipline, order, courtesy, responsibility, integration of religious values in the lives of students and most importantly also the planting of a sense of responsibility towards students by giving an understanding of the role and position as a student. This is also in accordance with the vision and mission of MAN 2 Tebo, namely: vision "the realization of students to be human beings who believe and devote, noble, smart personality, competitive, mastering science and technology, and able to actualize themselves in social life. Based on the results of the study, the researchers saw that the success factors of the madrasa principals in benchmarking madrassas at the madrasa which led to the transformation of madrasas were the existence of good cooperation from all parties in the madrasa, both madrasah principals, educators and education staff and students in the madrasa.

The implementation of madrasah management through Benchmarking conducted at MAN 1 Batang Hari is also oriented to improving the quality of madrasas by making the learning process quality, maximizing the use of madrasah facilities and infrastructure with classroom management that supports the comfort and safety of the learning process, students in the madrasa can actualize themselves in in the community according to the needs of the community such as the ability to be priests to pray, pray, lead yasinan, bertilil, berkhutbah and other Islamic activities through training conducted in madrasas and that is not less important is the planting of Islamic character values to participants student. This is also in accordance with the vision and mission of MAN 2 Tebo namely: vision "" Exemplary in Superior Behavior in Achievement ". Based on the results of the study, the researchers saw that the success factors of the madrasa principals in benchmarking madrassas at the madrasa which led to the transformation of madrasas were the existence of good cooperation from all parties in the madrasa, both madrasah principals, educators and education staff and students in the madrasa. Human resources in MAN 1 Batang Hari have also been qualified, as seen from the adequacy of teachers in MAN 1 Batang Hari and the teachers at MAN 1 Batang Hari who have doctoral / doctoral degrees, most of them have also taken S2 education and are active in training activities, education and training, seminars and writing scientific works, be they journals, books or articles.

The head of the madrasa as a leader who applies benchmarking in improving quality in the madrasa he leads will make the transformation in the madrasa itself. Improving the organization through benchmarking that leads to organizational transformation can be done with the concept of business process reengineering (BPR). In benchmarking in the concept of reengineering according to Bennis and Mische in Bhaswara et al, it was carried out in the following stages: stage 1: Creating a vision and setting goals, stage 2: benchmarking and defining success, stage 3: Innovating processes, stage 4: Transforming organizations, stages 5: monitor reengineered processes. 
Conduct a benchmarking process at the madrasa which leads to the transformation of the madrasa, using a re-engineering model from Bennis and Mische. Broadly speaking, based on the results of observations, documentation and interviews conducted by researchers based on the findings in the field and those described above, it can be seen that benchmarking is done by the madrasa principals through planning benchmarking, collecting data, analyzing data, and adapting benchmarking results can make the transformation in madrasas both the input, process, output, outcome and culture of the madrasa to achieve madrasas that have superior / competitive competitiveness. In the reengineering model of Bennis and Mische it did not involve everyone in the organization, but rather focused on the team that did the reengineering, besides that the transformation had not been seen in aspects of organizational culture. Thus from the results of this study the researchers concluded that in the process of benchmarking in the madrasa must involve all parties in the madrasa even though a team was also formed in conducting the benchmarking process in addition to transformation must also occur also in aspects of organizational culture.

The implementation of benchmarking in madrasas as an effort to transform madrasas to improve the quality of madrasas and lead to the transformation of madrasas in improving performance in Islamic education institutions is carried out comprehensively through: 1) adjusting the vision, mission and objectives of the school, 2) strategic environmental analysis, 3) determining benchmarking topics, 4) determine the superior institutions for benchmarking purposes, and 5) form a benchmarking team. The implementation of benchmarking studies in destination institutions uses interview / discussion, observation, and documentation methods to collect data. The data from the benchmarking study are then adapted and selected taking into account several factors, including; culture, human resource capacity and budgeting by adhering to the principle of "Keeping old things good and taking new things better". The implementation of madrasah head benchmarking in transforming madrasa is done through intense communication between leaders, subordinates, and all stakeholders of education can make the implementation of the strategy more effective, because it is able to detect as early as possible the various obstacles faced by subordinates. The openness and flexibility of a leader is also a very important principle as an effort to concern the leader of the needs of his subordinates. So that through this intense, open and flexible form of leader control there is a mutually beneficial relationship between leaders and subordinates. In general, the benefits obtained from benchmarking can be grouped into three major groups, namely (1) cultural transformation, benchmarking allows companies to set realistic new performance targets. This process plays a major role in convincing everyone in the organization of the target's credibility to be achieved. This can overcome the "not found here" syndrome and "we are different" reasons that are often raised as arguments for maintaining the status quo, (2) performance improvement, benchmarking allows transformation to find out certain gaps in performance and to choose processes that will be fixed. This can be useful for redesigning a product or service to meet or exceed customer expectations, (3) improving human resource capabilities, benchmarking provides the basis for training. In this study the benefits of the benchmarking process are the transformation that occurs in the madrasa in aspects, inputs, output processes and culture within the madrasa.

\section{Implications}

This study has theoretical implications, namely strengthening what Bennis and Mische said in Bhaswara et al while providing additional based on the results of research that to reengineer an 
organization is done in the following stages: stage 1: Creating a vision and setting goals, stage 2: benchmarking and define success, stage 3: Innovate the process, stage 4: Transform the organization, stage 5: monitor the process that is reengineered. The benchmarking application will produce various transformations, because applying benchmarking in the madrasa environment is a systematic and continuous learning process to analyze the best work procedures to create and achieve the best achievement goals and will result in transformations in the madrasa, improving madrasa performance, and improving human resource capacity in madrasas.

Based on the results of research conducted by researchers through observations, documentation and interviews that benchmarking madrasah principals is one process of comparing and measuring madrasah operations from the best performance originating from outside the madrasah conducted by the head of the madrasa which aims to transform madrasas from the prevailing conditions towards desired conditions carried out by individuals, groups within the madrasa in terms of reacting to internal and external dynamic forces are carried out through a benchmarking process that is conducting a madrasa self-evaluation, comparison with referral madrasas, reflection on madrasa performance and turning back on the benchmarking results of madrasas . For this reason, it can be seen that benchmarking by the madrasa principals through benchmarking planning, collecting data, analyzing data, and adapting the results of benchmarking can make the transformation in madrasas both input, process, output and outcome to reach madrasas that have superior / competitive competitiveness. In the reengineering model of Bennis and Mische it did not involve everyone in the organization, but rather focused on the team that did the reengineering, besides that the transformation had not been seen in aspects of organizational culture. Thus from the results of this study the researchers concluded that in the process of benchmarking in the madrasa must involve all parties in the madrasa and outside the madrasa. In the madrasa, namely the head of the madrasa, teaching staff, teaching staff, the community who are also customers of the madrasa, students are also institutions related to the education process in madrasas such as government, NGOs, and other institutions even though teams are formed in the benchmarking process. In the re-engineering model Bennis and Mische are not discussed on aspects of cultural transformation, even though organizational culture. Organizational culture is also needed to be transformed because organizational culture is also one that influences success in conducting benchmarking processes in madrasas, namely organizational culture that reflects the character of the institution and a healthy work climate.

\section{References}

[1] Abd. Kadim Masaong dan Arfan A. Tilome, Kepemimpinan Berbasis Multiple Intelligence: Sinergi Kecerdasan Intelektual, Emosional dan Spiritual untuk Meraih Kesuksesan yang Gemilang Bandung: ALFABETA, 2011.

[2] M.H. Matondang, Kepemimpinan Budaya Organisasi dan Manajemen Strategik Yogyakarta: Graha Ilmu, 2008.

[3] Gary Yukl, Kepemimpinan dalam Organisasi Jakarta: Indeks, 2015.

[4] Miftah Thoha, Kepemimpinan dalam Manajemen Jakarta: Rajawali Pers, 2012.

[5] Abd. Wahab H.S. dan Umiarso, Kepemimpinan Pendidikan dan Kecerdasan Spritual Jogjakarta: Ar-Ruzz Media, 2011.

[6] Mulyasa, Menjadi Kepala Sekolah Yang Profesional Bandung: Remaja Rosdakarya, 2006.

[7] Rusyan, Profisionalisme Kepala sekolah Jakarta: Pustaka Dinamika, 2012.

[8] Hasan Sodiqin dan Diding Nurdin, Kemampuan Manajerial Kepala Madrasah Dan Kinerja Mengajar Guru Dalam Mutu Pendidikan Jurnal Administrasi Pendidikan: Vol. XXIII No.2, 2016. 
[9] E. Mulyasa, Manajemen dan Kepemimpinan Kepala Sekolah (Jakarta: Bumi Aksara, 2015.

[10] M. Nur Nasution, Manajemen Mutu Terpadu: Total Quality Management Bogor: Ghalia Indonesia, 2015.

[11] Mustajab, Trilogi Membangun Sekolah Unggul: Kepemimpinan, Budaya Mutu, Benchmarking, Kebumen: Jurnal Saintifika Islamica IAINU Kebumen, Vol.2 No. 2, 2015.

[12] Teguh Triwiyanto, Standar Nasional Pendidikan Sebagai Indikator Mutu Layanan Manajemen Sekolah Malang: Jurnal Ilmu Pendidikan Universitas Negeri Malang, Vol 19. No. 2, 2013.

[13] Baharuddin dan Umiarso, Kepemimpinan Pendidikan Islam Antara teori dan Praktek Yokjakarta: Ar-Ruzz Media, 2012.

[14] Amin Widjaja Tunggal, Manajemen Mutu Terpadu Suatu Pengantar Jakarta: Rineka Cipta, 2005.

[15] M. Nur Nasution, Manajemen Mutu Terpadu (Total Quality Management) Bogor: Ghalia Indonesia, 2015.

[16] Gregory H. Watson, Strategic Benchmarking, Mengukur Kinerja Perusahaan Anda Dibandingkan Perusahaan-Perusahaan Terbaik Dunia Jakarta: Gramedia Pustaka Utama 1996.

[17] Bhaswara Aditya Wardhana, dkk, Usulan Perbaikan Proses Bisnis Dengan Konsep Business Process Reengineering: (Studi Kasus Permata Guest House, Jurnal Jati Undip, Vol. VIII, No. 1. 2013.

[18] Winardi, Manajemen Perubahan Jakarta: Kencana Prenada Media Group, 2008.

[19] Uhar Suharsaputra, Administrasi Pendidikan Bandung: Rosdakarya, 2010.

[20] Sudarwan Danim, Visi Baru Manajemen Madrasah Jakarta: Bumi Aksara, 2010.

[21] Onimus Amtu, Manajemen Pendidikan di Era Otonomi Daerah Bandung: Afabeta, 2013.

[22] Bambang Ismaya, Pengelolaan Pendidikan Bandung, Refika Aditama, 2015.

[23] Syafaruddin. Efektivitas Kebijakan Pendidikan: Konsep, Strategi, dan Aplikasi Kebijakan Menuju Organisasi Sekolah Efektif Jakarta: Rineka Cipta, 2008.

[24] Nur Efendi, Membangun Sekolah Efektif dan Unggul Yogyakarta: Lingkar Media, 2014.

[25] Direktorat Tenaga Kependidikan, Supervisi Akademik Dalam Peningkatan Profesionalisme Guru Jakarta: Departemen Pendidikan Nasioanal, 2007.

[26] E. Mulyasa, Menjadi Guru Profesional Menciptakan Pembelajaran Kreatif dan Menyenangkan Bandung: Remaja Rosdakarya, 2008.

[27] Udin Syafaruddin Saud, Pengembangan Profesi Guru Bandung: Alfabeta, 2009.

[28] Basrowi dan Suwandi, Memahami Penenlitian Kualitatif Jakarta: Rineka Cipta, 2009.

[29] Nana Syaodih Sukmadinata, Metode Penelitian Pendidikan Bandung: Program Pascasarjana Universitas Pendidikan Indonesia, Remaja Rosdakarya, 2007.

[30] Matthew B. Miles \& A. Michael Huberman, Analisis Data Kualitatif: buku sumber tentang Metodemetode Baru Jakarta: UI-Pres, 1992.

[31] Bhaswara Aditya Wardhana, dkk, Usulan Perbaikan Proses Bisnis Dengan Konsep Business Process Reengineering: (Studi Kasus Permata Guest House, Jurnal Jati Undip, Vol. VIII, No. 1. 2013 